\title{
Analisis Faktor yang Mempengaruhi Kejadian Demam Berdarah Dengue di Wilayah Kerja Puskesmas Way Kandis Bandar Lampung Tahun 2020
}

\author{
Ismalia Husna $^{1}$, Devita Febriani Putri ${ }^{1}$, Tusy Triwahyuni ${ }^{1}$, Guntur Batara Kencana ${ }^{2}$ \\ ${ }^{1}$ Departemen Parasitologi Fakultas Kedokteran Universitas Malahayati \\ ${ }^{2}$ Program Studi Kedokteran Fakultas Kedokteran Universitas Malahayati
}

\begin{abstract}
Abstrak
World Health Organization (WHO) melaporkan bahwa terjadi peningkatan jumlah kasus DBD khususnya di negara tropis seperti Indonesia. Di Bandar Lampung terjadi instabilitas pada Incidence Rate (IR) dari tahun 2010-2015 dan Tanjung Senang merupakan wilayah dengan angka kasus tertinggi yaitu 138 kasus. Tujuan penelitian ini untuk mengetahui faktor yang mempengaruhi kejadian Demam Berdarah Dengue (DBD) di Wilayah Kerja Puskesmas Way Kandis Bandar Lampung. Penelitian ini menggunakan desain penelitian case control. Sampel pada penelitian ini sebanyak 100 sampel dari 50 kasus DBD dan 50 kontrol. Teknik pengambilan sampel pada penelitian ini yaitu total sampling pada kelompok kasus dan random sampling pada kelompok kontrol. Analisa data yang digunakan adalah chi-square test. Hasil analisis statistik menggunakan uji Chi-square menunjukan variabel yang berhubungan dengan kejadian DBD adalah pengetahuan ( $p$-value $=0,02$; $\mathrm{OR}=0,40 ; 95 \% \mathrm{CI}: 0,35$ - 1,72) dan jumlah kontainer ( $p$-value $=0,01 ; \mathrm{OR}=3,02 ; 95 \%$ CI:1,26-7,20). Variabel yang tidak berhubungan antara lain pendidikan, pekerjaan, perilaku, ketersediaan tutup kontainer, keberadaan kawat kassa dan jarak antar rumah karena $p$ value $>0,05$. Simpulan dari penelitian ini adalah pengetahuan dan jumlah container merupakan faktor yang berpengaruh terhadap kejadian DBD di Kelurahan Way Kandis.
\end{abstract}

Kata Kunci : DBD, Faktor yang Mempengaruhi, Way Kandis

\section{Analysis of Factors Which Affecting The Incidence of Dengue Hemorraghic Fever at Puskesmas Way Kandis Bandar Lampung in 2020}

\begin{abstract}
The World Health Organization (WHO) reports an increasing number of dengue cases especially in tropical countries such as Indonesia. In Bandar Lampung instability occurred at the Incidence Rate (IR) from 2010-2015 and Tanjung Senang was the region with the highest number of cases, namely 138 cases. Dengue Haemorraghic Fever (DHF) in the Way Kandis Community Health Center in Bandar Lampung. This study used a case control research design. The sample in this study amounted to 100 samples from 50 DHF cases and 50 controls. The sampling technique in this study was total sampling in the case group and random sampling in the control group. Analysis of the data used the chi-square test. The results of statistical analysis was using the Chi-square test showed that variables related to the incidence of DHF were knowledge ( $\mathrm{p}$-value $=0.02 ; \mathrm{OR}=0.40 ; 95 \% \mathrm{CI}$ : 0.35 -1.72 ) and the number of containers ( $\mathrm{p}$-value $=0.01 ; \mathrm{OR}=3.02 ; 95 \%$ CI: 1.26-7.20). Variables that were not related to DHF cases were education, occupation, behavior, approval of container cover, approval of wire mesh and distance between houses because of $p$ value $>0.05$. The conclusion of this study was the knowledge and the amount of container that represents the factors that affecting the incidence of DHF in the Way Kandis Village.
\end{abstract}

Keywords: : DHF, Factors Affecting, Way Kandis

Korespondensi: Ismalia Husna, Departemen Parasitologi, Fakultas Kedokteran, Universitas Malahayati, Jalan Pramuka No. 27 Kemiling Bandar Lampung, mobile 081280318036, e-mail ismalia@ malahayati.ac.id 


\section{Pendahuluan}

Demam Berdarah Dengue (DBD) termasuk masalah kesehatan di negara yang beriklim tropis. World Health Organization (WHO) melaporkan bahwa terjadi peningkatan jumlah kasus DBD dari 2,2 juta pada tahun 2010 menjadi 3,2 juta kasus pada tahun 2015. Daerah yang paling parah terkena dampak DBD yaitu Amerika, Asia Tenggara dan Pasifik Barat. Berdasarkan laporan WHO pula, Indonesia merupakan negara dengan kasus DBD tertinggi di Asia Tenggara (Lumingas, 2017; Husna et al, 2019).

Laporan kasus di Indonesia pertama kali diketahui di kota Surabaya pada tahun 1968 dengan total terinfeksi 58 orang dan 24 orang diantaranya meninggal. Kasus DBD di Indonesia menunjukkan peningkatan setiap tahun, seperti pada tahun 2016 terjadi peningkatan jika dibandingkan dengan kasus tahun 2015 dari 204.171 kasus menjadi 129.650 kasus. Angka kematianpun meningkat pada tahun 2016 yaitu 1.598 orang, sedangkan pada tahun 2015 sebanyak 1.071 orang. Incidence Rate (IR) atau angka morbiditas DBD di tahun 2016 juga meningkat dari tahun 2015, yaitu 50,75 menjadi 78,85 per 100.000 penduduk, meskipun Case Fatality Rate (CFR) atau angka kematian mengalami penurunan dari $0,83 \%$ di tahun 2015 menjadi $0,78 \%$ di tahun 2016. (Husna et al, 2019; Angelina \& Rudatin, 2019).

Incidence Rate (IR) atau angka kesakitan di Provinsi Lampung tahun 2010-2015 mengalami instabilitas karena tercatat pada tahun 2010 IR sebesar 22,88 per 100.000 penduduk lalu menurun menjadi 20,03 di tahun 2011, namun mengalami peningkatan di tahun 2012 sebesar 68,44 per 100.000 penduduk. Setelah itu, pada tahun 2013 IR sebesar 58,08 mengalami penurunan menjadi 16,80 per 100.000 penduduk di tahun 2014, dan pada tahun 2015 tercatat IR meningkat kembali sebesar 36,91 (Dinkes Provinsi Lampung, 2015).

Berdasarkan data Badan Statistik Kota Bandar Lampung tahun 2018 salah satu daerah yang memiliki angka kejadian DBD yang tinggi di Kota Bandar Lampung adalah Kecamatan Tanjung Senang. Pada tahun 2018, di Kecamatan Tanjung Senang terdapat kasus DBD sebanyak 138 kasus, hal ini menjadikan Tanjung Senang sebagai wilayah yang memiliki kasus DBD tertinggi di Kota Bandar Lampung.

Faktor risiko yang mempengaruhi peningkatan angka kejadian kasus DBD diantaran adalah faktor individu, virus, dan epidemiologi. Faktor individu meliputi usia, jenis kelamin, ras, status gizi, infeksi sekunder, dan respon inang serta dapat ditinjau pula dari faktor pengetahuan (kognitif) individu, sikap (afektif) seseorang dan tindakan (konatif) yang dilakukan terkait DBD. Faktor penyebab (agent) terdiri dari jenis dan serotipe virus dengue, serta vektor penyakit DBD yaitu Aedes aegypti dan Aedes albopictus. Sedangkan faktor epidemiologi yaitu jumlah kasus, identifikasi virus, virulensi, hiperendemik, kondisi lingkungan seperti fisik (kepadatan rumah, keberadaan kontainer, suhu, kelembaban, curah hujan), biologis (keberadaan tanaman hias, pekarangan, jentik nyamuk), dan sosial (pendidikan, pekerjaan, penghasilan, mobilitas penduduk, kepadatan penduduk, pemberantasan sarang nyamuk) (Lardo et al, 2018; Rismawati \& Nurmala, 2017; Fransisco et al, 2018).

Faktor-faktor lain yang dapat menyebabkan peningkatan angka kejadian kasus DBD berdasarkan penelitian Lumingas (2017) adalah ketersediaan tutup kontainer tempat penampungan air di rumah-rumah penduduk, dan penelitian yang dilakukan oleh Novrita et al (2017) juga menyebutkan adanya keterkaitan antara pemasangan kawat kasa dengan angka kasus kejadian DBD, serta adanya dugaan jarak antar rumah penduduk menjadi salah satu faktor penyebab meningkatnya angka kejadian kasus DBD.

\section{Metode}

Penelitian ini merupakan penelitian analitik observasional dengan desain penelitian case control. Penelitian ini dilakukan di Kelurahan Way Kandis, pada bulan Januari 2020. Populasi kasus pada penelitian ini adalah masyarakat yang ada di wilayah Kelurahan Way Kandis, yang terdata di Puskesmas Way Kandis Bandar Lampung dengan diagnosis DBD tahun 2018 s.d. 2020, yaitu sebanyak 50 kasus dan populasi kontrol juga berjumlah 50 kelompok yang merupakan masyarakat yang tidak menderita DBD dan tidak menunjukkan gejala klinis DBD yang tinggal di Kelurahan Way Kandis, Kecamatan Tanjung Senang, Bandar Lampung.

Total sampel pada penelitian ini adalah 100 sampel. Teknik sampling yang digunakan untuk menentukan jumlah sampel pada kasus adalah total sampling, dimana seluruh populasi kasus dijadikan sampel penelitian, yaitu 50 sampel kelompok kasus. Dan kelompok kontrol diambil secara acak menggunakan random sampling. 
Instrumen yang digunakan adalah lembar informed consent, data demografi, data pengetahuan, data perilaku, data kondisi lingkungan rumah dan lembar observasi keberadaan kontainer. Analisa data yang digunakan adalah Chi-square test.

\section{Hasil}

Penelitian dilakukan di Kelurahan Way Kandis dengan jumlah 100 responden yang terdiri dari 50 kelompok responden kasus dan 50 kelompok responden kontrol.

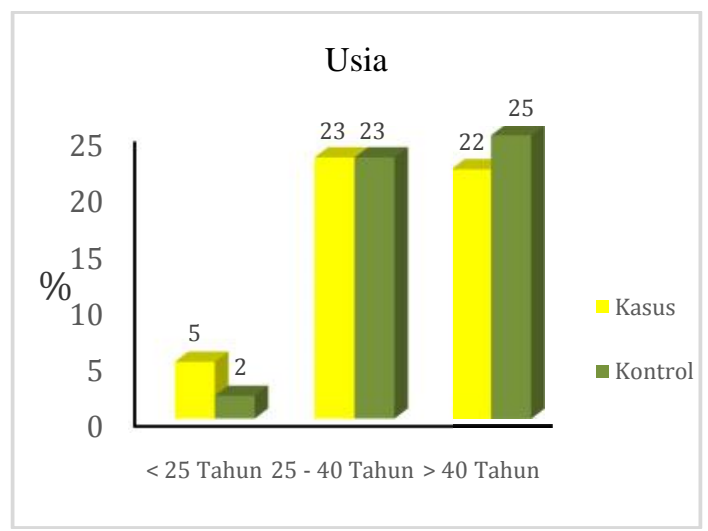

Gambar 1. Grafik Distribusi Kelompok RespondenBerdasarkan Usia

Berdasarkan Gambar 1. diatas dapat dilihat bahwa pada kelompok kasus usia $<25$ tahun sebanyak 5 responden (5\%), pada kelompok usia 25 - 40 tahun sebanyak 23 responden (23\%) dan pada usia > 40 tahun sebanyak 22 responden (22\%). Sedangkan pada kelompok control usia $<25$ tahun sebanyak 2 responden (2\%), pada kelompok usia $25-40$ tahun sebanyak 23 responden $(23 \%)$ dan pada kelompok usia > 40 tahun sebanyak 25 responden $(25 \%)$.

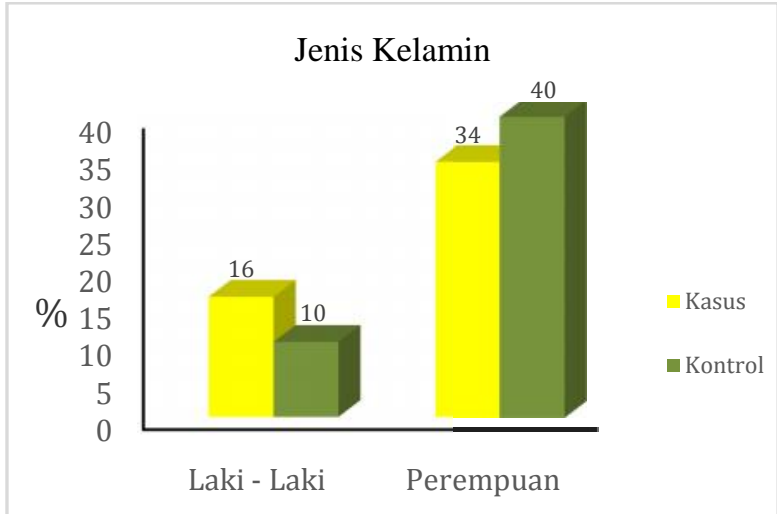

Gambar 2. Grafik Distribusi Kelompok Responden Berdasarkan Jenis Kelamin
Berdasarkan Gambar 2. diatas dapat disimpulkan untuk jenis kelamin responden pada kasus dan kontrol yang terbanyak adalah perempuan yaitu sebanyak 34 responden (34\%) untuk kelompok kasus dan 40 responden (40\%) untuk kelompok kontrol. Sedangkan laki - laki sebanyak 16 responden $(16 \%)$ untuk kelompok kasus dan 10 responden (10\%) untuk kelompok kontrol. Hal ini dapat dijelaskan untuk kasus dan kontrol tertinggi berjenis kelamin perempuan karena berdasarkan penelitian dilapangan perempuan lebih cenderung memiliki aktivitas di dalam rumah, berbeda dengan laki - laki yang memiliki aktivitas diluar rumah sehingga sulit ditemui oleh peneliti.

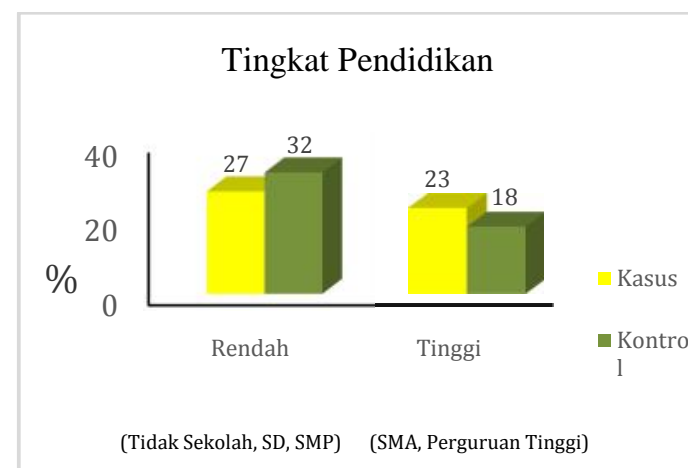

Gambar 3. Grafik Distribusi Kelompok Responden Berdasarkan Tingkat Pendidikan

Berdasarkan gambar 3. diatas menjelaskan bahwa untuk tingkat Pendidikan responden dikategorikan menjadi dua yaitu Pendidikan rendah (tidak tamat sekolah, tamat SD, tamat SLTP/setingkat SMP) dan Pendidikan tinggi (yaitu SLTA keatas). Tingkat Pendidikan yang rendah pada kasus sebanyak 27 responden (27\%) dan pada tingkat Pendidikan yang tinggi pada kasus sebanyak 23 responden (23\%). Sedangkan pada kontrol responden yang tingkat pendidikannya rendah sebanyak 32 responden (32\%) dan tingkat Pendidikan yang tinggi sebanyak 18 responden (18\%). 


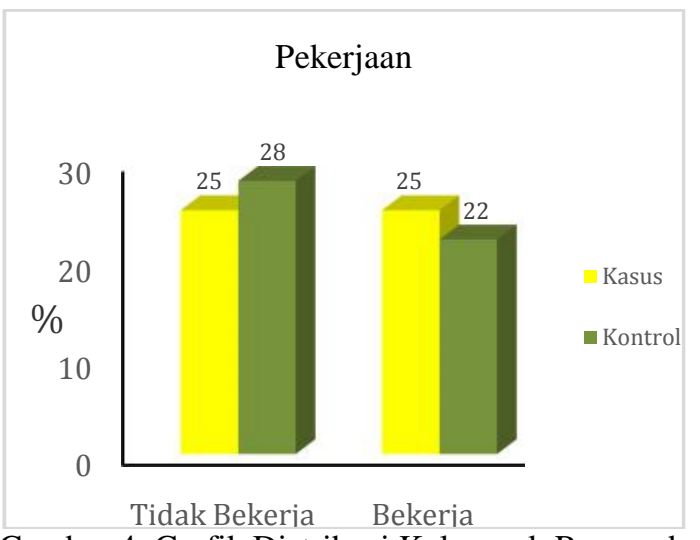

Gambar 4. Grafik Distribusi Kelompok Responden Berdasarkan Pekerjaan
Berdasarkan gambar 4. diatas menjelaskan bahwa pekerjaan responden dikategorikan menjadi dua yaitu tidak bekerja dan bekerja. Responden yang tidak bekerja pada kelompok kasus sebanyak 25 responden $(25 \%)$ dan yang bekerja sebanyak 25 responden (25\%). Sedangkan untuk kontrol yang tidak bekerja sebanyak 28 responden (28\%) dan bekerja 22 responden $(22 \%)$.

Analisis bivariat faktor risiko kejadian DBD di wilayah Kerja Puskesmas Way Kandis Bandar Lampung disajikan pada Tabel 1. sebagai berikut:

Tabel 1. Analisis Bivariat Faktor yang Mempengaruhi Kejadian Demam Berdarah Dengue di Kelurahan Way Kandis

\begin{tabular}{|c|c|c|c|c|c|c|}
\hline \multirow{2}{*}{ Variabel } & \multicolumn{2}{|c|}{ Kasus } & \multicolumn{2}{|c|}{ Kontrol } & \multirow{2}{*}{$\mathrm{p}$-value } & \multirow{2}{*}{$\begin{array}{c}\text { OR } \\
(95 \% \mathrm{CI})\end{array}$} \\
\hline & $\mathrm{n}$ & $\%$ & $\mathrm{n}$ & $\%$ & & \\
\hline \multicolumn{7}{|l|}{ Tingkat Pendidikan } \\
\hline Rendah & 27 & 54,0 & 32 & 64,0 & \multirow{2}{*}{0,39} & 0,66 \\
\hline Tinggi & 23 & 46,0 & 18 & 36,0 & & $(0,29-1,47)$ \\
\hline \multicolumn{7}{|l|}{ Pekerjaan } \\
\hline TidakBekerja & 25 & 50,0 & 28 & 56,0 & \multirow{2}{*}{0,54} & 0,78 \\
\hline Bekerja & 25 & 50,0 & 22 & 44,0 & & $(0,35-1,72)$ \\
\hline \multicolumn{7}{|l|}{ Pengetahuan } \\
\hline Kurang Baik & 20 & 40,0 & 31 & 62,0 & \multirow{2}{*}{0,02} & 0,40 \\
\hline Baik & 30 & 60,0 & 19 & 38,0 & & $(0,35-1,72)$ \\
\hline \multicolumn{7}{|l|}{ Perilaku } \\
\hline Kurang Baik & 39 & 78,0 & 44 & 88,0 & \multirow{2}{*}{0,18} & 0,48 \\
\hline Baik & 11 & 22,0 & 6 & 12,0 & & $(0,16-1,43)$ \\
\hline \multicolumn{7}{|l|}{ Jumlah Kontainer } \\
\hline$<3$ & 11 & 22,0 & 23 & 46,0 & \multirow{2}{*}{0,01} & 3,02 \\
\hline$\geq 3$ & 39 & 78,0 & 27 & 54,0 & & $(1,26-7,20)$ \\
\hline \multicolumn{7}{|l|}{ Ketersediaan Tutup Kontainer } \\
\hline Tidak Tertutup & 34 & 68,0 & 34 & 68,0 & \multirow{2}{*}{1,00} & 1,00 \\
\hline Tertutup & 16 & 32,0 & 16 & 32,0 & & $(0,43-2,31)$ \\
\hline \multicolumn{7}{|l|}{ Keberadaan Kawat Kassa } \\
\hline Tidak Memakai Kawat Kassa & 31 & 62,0 & 30 & 60,0 & \multirow{2}{*}{0,83} & 0,83 \\
\hline Memakai Kawat Kassa & 19 & 38,0 & 20 & 40,0 & & $(0,48-2,43)$ \\
\hline \multicolumn{7}{|l|}{ Jarak Antar Rumah } \\
\hline$<40 \mathrm{~m}$ & 46 & 92,0 & 41 & 82,0 & \multirow{2}{*}{0,13} & 2,52 \\
\hline $40-100 \mathrm{~m}$ & 4 & 8,0 & 9 & 18,0 & & $(0,72-8,81)$ \\
\hline
\end{tabular}

Variabel pengetahuan dan jumlah kontainer secara statistik signifikan berhubungan dengan kejadian DBD karena $\mathrm{p}$ value $<0,05$, yaitu $\mathrm{p}$ value masing-masing adalah 0,02 dan 0,01. Sedangkan variabel tingkat pendidikan $(\mathrm{p}=0,39)$, pekerjaan $(\mathrm{p}=0,54), \quad$ perilaku $(\mathrm{p}=0,18)$, ketersediaan tutup kontainer $(\mathrm{p}=1,00)$, keberadaan kawat kassa $(p=0,83)$ dan jarak antar rumah $(\mathrm{p}=0,13)$ tidak memiliki hubungan signifikan dengan kejadian DBD di Wilayah Kerja Puskesmas Way Kandis Bandar Lampung karena $\mathrm{p}$ value $>0,05$.

\section{Pembahasan}

Berdasarkan penelitian yang telah dilakukan di wilayah kerja Puskesmas Way Kandis menunjukkan bahwa morbiditas tertinggi terhadap kasus Demam Berdara Dengue (DBD) ditemukan pada kelompok usia 25-40 tahun, hal tersebut dapat dihubungkan dengan perbedaan gaya hidup, waktu paparan di dekat vektor, tidur tanpa menggunakan kelambu, dan pencegahan penyakit yang tidak begitu dipikirkan oleh kelompok umur tersebut (Toan et al, 2014).

Demam Berdarah Dengue (DBD) merupakan penyakit yang disebabkan oleh virus 
dengue yang ditransmisikan oleh nyamuk Aedes aegypti dan Aedes albopictus. Transmisi dilakukan oleh nyamuk betina melalui venereal transmission, lalu telur yang fertil akan menginfeksi melalui jalur trans-ovarian dan hal tersebut dapat menyebabkan transmisi virus dengue terdistribusi ke area yang luas (Putri et $a l$, 2018). Berdasarkan hasil penelitian yang telah dilakukan di wilayah kerja Puskesmas Way Kandis diketahui bahwa pengetahauan yang dimiliki responden mengenai DBD sangat berpengaruh terhadap kejadian DBD di wilayah tersebut, hal tersebut terlihat dari nilai $\mathrm{p}=0,02$ dengan nilai $\mathrm{OR}=0,40$ yang dapat diartikan bahwa responden yang memiliki pengetahuan yang baik memiliki risiko 2,5 kali lebih kecil terkena DBD dibandingkan dengan responden yang kurang memahami DBD. Hal tersebut juga didukung oleh penelitian Novrita et al (2017) dan Torondek et al (2019) yang menunjukkan adanya hubungan antara tingkat pengetahuan masyarakat dengan kejadian DBD ( $\mathrm{p}=0,015$ dan $\mathrm{p}=0,028$ ).

Faktor lingkungan merupakan salah satu faktor yang menyebabkan transmisi DBD karena mendukung perkembangbiakan nyamuk (Sarfraz et al, 2012). Pada penelitian ini ditunjukkan oleh banyaknya jumlah kontainer, karena peneliti menemukan bahwa masyarakat di Kelurahan Way Halim rata-rata menampung air menggunakan ember dan drum untuk keperluan sehari-hari. Setiap rumah rata-rata memiliki >3 buah kontainer, hal tersebut berisiko dalam peningkatan kejadian DBD karena menurut Gama \& Betty (2010) rumah dengan jumlah kontainer $>3$ memiliki risiko untuk mengalami DBD dengan nlai $\mathrm{p}=0,01$ dikarenakan dapat meningkatnya perkembangbiakan larva nyamuk Ae.aegypti.

Tingkat pendidikan pada masing-masing responden diyakini dapat mempengaruhi angka kejadian kasus DBD, Siregar et al (2015) menyebutkan bahwa semakin tinggi tingkat pendidikan maka semakin rendah angka kejadian kasus DBD. Namun pada penelitian ini tingkat pendidikan tidak berpengaruh terhadap angka kejadian kasus DBD, hal tersebut dapat terjadi karena status responden yang memiliki tingkat pendidikan Sarjana Ekonomi belum tentu memahami epidemiologi DBD dibandingkan dengan kader kesehatan yang berstatus tamatan SMA. Novrita et al (2017) juga menyatakan bahwa nilai $\mathrm{p}=0,134$ terhadap tingkat pendidikan dan angka kasus DBD, yang artinya tidak ada hubungan yang signifikan antara tinggi rendahnya pendidikan responden dengan meningkat atau menurunnya jumlah kasus DBD di suatu wilayah.

Begitu pula dengan jenis pekerjaan dan perilaku pada penelitiannya ini tidak ada hubungan yang signifikan terhadap kejadian DBD. Berdasarkan hasil pengamatan yang didapatkan peneliti dari wawancara dengan responden di Kelurahan Way Kandis diperoleh informasi bahwa kebanyakan dari responden adalah ibu rumah tangga dimana segala aktivitasnya berada di dalam rumah sehingga responden jarang untuk berpergian keluar rumah dan untuk responden yang bekerja kebanyakan dari responden adalah petani sehingga mereka berangkat pada pagi hari dan pulang sore hari dimana menurut Camara (2010) pagi dan sore hari adalah waktu dimana nyamuk penyebab DBD mencari makan, sedangkan kebun merupakan salah satu habitat dari nyamuk penyebab DBD, sehingga pada responden yang berkerja maupun tidak bekerja masih dapat terkena DBD.

Sedangkan perilaku responden yang baik seperti tidak menggantung pakaian di dinding kamar ataupun dibelakang pintu, menutup kontainer dan sering mengubur barang bekas ternyata masih bisa terkena DBD dikarenakan jarak antar rumah responden yang berdekatan dengan responden yang memiliki perilaku yang kurang baik dalam pencegahan penyakit ini, sehingga tidak adanya hubungan antara perilaku dan jarak antar rumah dengan kejadian DBD, karena kedua faktor tersebut saling terkait. Hal ini sejalan dengan penelitian yang dilakukan Handoyo et al (2015) bahwa tidak ada hubungan $(\mathrm{p}=0,659)$ antara perilaku masyarakat dengan kejadian DBD di pesisir pantai Kota Tarakan. Namun penelitian Tangyong et al (2013) menyebutkan adanya hubungan antara sikap dengan kejadian DBD di Kota Makassar, hal tersebut dimungkinkan karena adanya perbedaan perilaku dan kebiasaan dari masyarakat yang berbeda wilayah.

Faktor lain yang dapat mempengaruhi atau dapat meningkatkan kejadian DBD di suatu wilayah adalah ada tidaknya tutup kontainer yang dimiliki oleh responden. Penelitian yang dilakukan Toan (2014) menyatakan bahwa responden yang kontainernya tidak ditutup memiliki risiko 7-9 kali lebih besar terkena penyakit DBD, karena kontainer yang tidak ditutup dapat menjadi tempat nyamuk Ae. aegypti menaruh telurnya yang kemudian dapat berkembang menjadi larva dan pupa sampai menjadi dewasa (Putri et $a l, 2018)$. Namun berbeda dengan penelitian sebelumnya, pada penelitian ini didapatkan 
hasil tidak signifikannya antar tutup kontainer dengan kejadian DBD di Kelurahan Way Kandis. Hal tersebut dikarenakan perbedaan waktu pengambilan sampel, pada penelitian Toan et al (2014) data dikumpulkan sesaat setelah terjadinya banjir di daerah Hanoi, Vietnam. Sedangkan data pada penelitian ini dikumpulkan saat musim kemarau di Way Kandis sehingga perkembangbiakan dari nyamuk Ae. aegypti tidak sebanyak penelitian Toan et al (2014).

Sedangkan pemakaian kawat kassa tidak terlalu berhubungan dengan kejadian DBD di wilayah kerja Puskesmas Way Kandis karena menurut observasi peneliti masih banyak yang tidak menggunakan kawat kassa di tiap lubang ventilasi, dan ada juga pada beberapa rumah yang sudah memasang kawat kassa tetapi pemasangannya belum menyeluruh ke semua ruangan, kebanyakan yang di pasang kawat kassa hanya kamar tidur sedangkan ruangan lain seperti ruang tamu belum di pasang kawat kassa. Hal ini memudahkan nyamuk untuk masih bisa masuk ke dalam rumah. Hal tersebut sejalan dengan penelitian Handoyo et al (2015) yang menyatakan bahwa tidak ada hubungan antara karakteristik rumah dengan kejadian DBD, dimana karakteristik rumah dalam variabel tersebut adalah pemasangan kawat kasa dengan $p$ value sebesar 0,775 .

Pemasangan kawat kasa pada ventilasi akan menyebabkan semakin kecilnya kontak nyamuk dengan penghuni rumah sehingga nyamuk tidak dapat masuk ke dalam rumah dan menjadikanpenghuni rumah terlindung dari gigitan nyamuk (Novrita et al, 2017), namun pemasangan yang kurang tepat akan tetap mengakibatkan masuknya nyamuk dan mentransmisikan penyakit DBD.

Selain itu, nyamuk Ae. aegypti betina memiliki kemampuan terbang 40 meter dan maksimal 100 meter, namun jarak terbangnya tergantung pada ketersedian tempat untuk bertelur. Jika tempat bertelur ada di sekitar rumah, maka nyamuk tidak terbang jauh. Akan tetapi secara pasif, misal karena terbawa oleh angin atau kendaraan, nyamuk dapat berpindah lebih jauh. Karena itulah jarak antar rumah dapat mempengaruhi penyebaran nyamuk $A e$. aegypti dari satu rumah ke rumah yang lainnya. Semakin dekat jarak antar rumah, maka semakin mudah pula nyamuk menyebar ke rumah yang saling bersebelahan (Cecep, 2011).

Responden di wilayah kerja Puskesmas Way Kandis yang memiliki jarak antar rumah $<40$ meter ternyata masih ada yang tidak pernah menderita DBD, hal ini dapat dijelaskan meskipun pada anggota keluarga tetangga ada yang menderita DBD, tidak serta merta membuatnya dapat berpindah ke rumah tetangga sebelahnya meskipun jaraknya dekat karena ada faktor seperti bahan-bahan pembuat rumah, konstruksi rumah, warna dinding dan pengaturan barang-barang dalam rumah, selain itu kondisi rumah bersih atau tidak juga menjadi perhatian apakah disenangi atau tidak disenangi oleh nyamuk. Selain itu, faktor lain yang kemungkinan besar ikut mempengaruhi adalah perilaku pencegahan gigitan nyamuk dengan menggunakan obat anti nyamuk baik oles, bakar, maupun semprot. Demikianpun pada responden yang memiliki jarak rumah 40 $100 \mathrm{~m}$ ternyata masih ada yang pernah menderita DBD. Nyamuk Ae. aegypti memiliki jarak terbang $100 \mathrm{~m}$ sehingga nyamuk dapat berpindah dari rumah satu ke rumah yang lain. Hal tersebut sejalan dengan penelitian Apriliana et al (2017) yang melaporkan bahwa tidak ada hubungan antara jarak rumah responden dengan kejadian DBD di Gagakan Kecamatan Sambong Kabupaten Blora.

Simpulan dari penelitian ini adalah faktor-faktor yang berhubungan dengan kejadian DBD di lingkungan wilayah kerja Puskesmas Way Kandis, Bandar Lampung yaitu tingkat pengetahuan dan jumlah kontainer di rumah responden. Sedangkan faktor tingkat pendidikan, pekerjaan, perilaku, ketersediaan tutup kontainer, keberadaan kawat kassa dan jarak antar rumah tidak memiliki hubungan signifikan dengan kejadian DBD di Wilayah Kerja Puskesmas Way Kandis Bandar Lampung.

Saran yang ingin disampaikan peneliti adalah perlu dilakukan penelitian lebih lanjut mengenai keterkaitan keberadaan larva di rumah responden dengan kejadian DBD di wilayah tersebut dengan memperhatikan faktorfaktor seperti pemeliharaan predator alami larva, ada tidaknya tanaman hias yang menggenang air, rutinitas pencegahan penyakit DBD oleh responden, dan faktor-faktor lain yang terkait.

\section{Daftar Pustaka}

Angelina,C.R. \& Rudatin, W. (2019). Factors Related with Dengue Haemorraghic Fever Incidence in 2008-2017. Unnes Journal of Public Health 8(1): 64-72.

Apriliana, R., Retnaningsih, D., \& Damayanti, W.P. (2017). Hubungan Kondisi Lingkungan dengan Kejadian Demam 
Berdarah Dengue (DBD) pada Keluarga di Gagakan Kecamatan Sambong Kabupaten Blora Tahun 2017. Jurnal NERS STIKES Widya Husada Semarang 2(1).

Camara, T.L. (2010). Activity Patterns of Aedes aegypti and Aedes albopictus (Diptera: Culicidae) Under Natural and Artificial Conditions. Oecologia Australis 14(3): 737-744.

Cecep, D.S. (2011). Vektor Penyakit Tropis. Yogyakarta: Gosyen.

Dinkes Provinsi Lampung. (2015). Profil Kesehatan Provinsi Lampung Tahun 2015. Diakses dari http://www.depkes.go.id/

Francisco, F., Kaunang, W.P., dan Kekenusa, J.S.

(2018). Hubungan Antara Faktor Lingkungan Biologis dengan Kejadian Penyakit Demam Berdarah Dengue (DBD) di Wilayah Kerja Puskesmas Tikala Manado. Community Health 2(5).

Gama, T.A. \& Betty, R.F. (2010). Analisis Faktor Risiko Kejadian Demam Berdarah Dengue di Desa Mojosongo Kabupaten Boyolali. Eksplanasi 5(2): 1-9.

Handoyo, W., Hestiningsih, \& Martini. (2015). Hubungan Sosiodemografi dan Lingkungan Fisik dengan Kejadian Demam Berdarah Degue (DBD) pada Masyarakat Pesisir Pantai Kota Tarakan. Jurnal Kesehatan Masyarakat (e-journal) 3(3): 186-195.

Husna, I., Endah, S., Tundjung, T.H., Yogi, K, Endah, K.P., Rofiqul, U. Bibin, B. A. (2019). Utilization of Basil Leaf Extract as Anti-Mosquito Repellent: A Case Study of Total Mosquito Mortality (Aedes aegypti $3^{\text {rd }}$ Instar). IOP Conf. Series: Journal of Physics 1467.

Lardo, S., Soesaty, M.H.N.E, Juffrie, and Umniyati, S.R. (2018). The Worsening Factors of Dengue Haemorraghic Fever (DHF) Based on Cohort Study with Nested Case-Control in a Tertiary Hospital. IOP Conf. Series: Earth and Environmental Science 125.
Lumingas, E. R. (2017). Faktor-Faktor yang Berhubungan dengan Kejadian Demam Berdarah. Fakultas Kesehatan Masyarakat Universitas Sam Ratulangi Manado 9(3)

Novrita, B., Mutahar, R. dan Purnamasari, I. (2017). Analisis Faktor Risiko Kejadian Demam Berdarah Dengue di Wilayah Kerja Puskesmas Celikah Kabupaten Ogan Komering Ilir. Jurnal Ilmu Kesehatan Masyarakat 8(1).

Putri,D.F., Widya, A., Sugeng, J.M. (2018). The Potency of Polygamy Behavior in Aedes aegypti Mosquitoes by Venereal Transmission Dengue Virus. KEMAS 13(3): 382-388.

Rismawati, S. N. \& Nurmala, I. (2017). Hubungan Perilaku Host dan Environment dengan Kejadian DBD di Wonokusumo Surabaya. Jurnal Berkala Epidemiologi 5(3): 383-392.

Sarfraz, M.S., Tripathi, N.K., Tipdecho, T., Thongbu, T., Kerdthong, P., Souris, M. (2012). Analyzing the Spatio-Temporal Relationship between Dengue Vector Larval Density and Land-Use Using Factor Analysis and Spatial Ring Mapping. BMC Public Health 12(1): 1.

Siregar, F.A., Mohamed R.A., Julia, O., Sori, M.S., Teguh, S., Tri, M., and Nurul, H. (2015). Social and Environmental Determinants of Dengue Infection Risk in North Sumatera Province, Indonesia. Asian Journal of Epidemiology 8(2):2335.

Tangyong, S.I., Askar., Sri, D. (2013). Hubungan Pengetahuan dan Sikap dengan Perilaku Masyarakat dalam Pencegahan Demam Berdarah Dengue di Wilayah Kerja Puskesmas Tamanlarea Makassar. Jurnal Ilmu Kesehatan Diagnosis 2(5): 62-68.

Toan, D.T.T., Hoat, L.N., Hu, W., Wright, P., Martens, P. (2014). Risk Factors Asspciated with an Outbreak of Dengue Fever/ Dengue Haemorraghoc Fever in Hanoi, Vietnam. Epidemiology and Infection 143(8): 1594-1598. 
Torondek, J., Wulan, P.J.K., dan Windy, W. (2019). Hubungan Antara Pengetahuan dan Tindakan Pencegahan dengan Kejadian Demam Berdarah Dengue (DBD) di Lingkungan III Kelurahan Airmadidi Atas Kabupaten Minahasa Utara. KESMAS 8(7). 